\title{
A Study on the Influencing Factors of International Investments between China and Europe
}

\author{
Houda bousfiha \\ Zhang ping \\ Zhejiang University of science and technology \\ 11 Rue de la destinee Cergy le haut, France \\ E-mail: bousfiha.houda@gmail.com \\ ZHEJIANG UNIVERSITY OF SCIENCE AND TECHNOLOGY \\ School of Economics, 318 Liuhe Rd, Xihu, Hangzhou, Zhejiang, China \\ E-mail: internationaloffice@126.com
}

\begin{abstract}
China and Europe are two big economies in the world, and there is much investment between them. As we know China has been investing almost in all around the world, Chinese investments in Europe have begun in recent years, and have become a symbol of Europe-China relations. According to data by the Rhodium Group, the amount of Chinese FDI in the EU has increased approximately 37 billion Euros in the first half of 2016, comparing with only 1.6 billion Euros in 2010.A big part of Chinese direct investment is mainly concentrated in the major economies in southern Europe or we can call it the BIG 3, as the UK, France and Germany all together.

DOI: $10.7176 / \mathrm{EJBM} / 13-6-04$

Publication date:March $31^{\text {st }} 2021$

\section{Significance of the topic}

Here are some data about EU investment into China:

However, compared with China's investment in the EU, EU investment in China is less. Here are some data about EU investment into China: the average size of transactions has significantly increased from 66 million dollars to 245 million dollars in 2 years. 2018 has seen an important number of deals over $\$ 1$ billion. The increase deal size is especially for acquisitions: BMW's pending acquisition of an additional $25 \%$ stake in its Chinese joint venture will be the largest EU acquisition in China ever (estimated at $\$ 4.2$ billion). The German carmaker company BMW is paying around 4 billion dollars to take control of its business In China, it's buying a majority stake in its local partner, Brilliance China Automotive Holdings, usually automakers have to operate in 50-50 partnership, but in this way, BMW will be the first to have the $75 \%$ stake.

The question that should be asked is: there is asymmetry between the investment from China to EU and the investment from EU to China. According to statistics, the amount of Chinese direct investment into Europe has totally exceeded the declining flows of annual European direct investments into China. In this way, some research deserves to be done. This paper chooses this topic and wants to find the influencing factors of International Investments between China and Europe. Finally based on the research, it can better provide policy suggestions for the international investment and development of China and Europe.
\end{abstract}

\section{Research status analyses in China and abroad}

2.1 Theoretical literature review

2.1.1 Definition of international investment

According to CFA institute, International Investments are those investments that are made outside the domestic markets andoffer portfolio diversification and opportunities for risk minimization. An investor can make international investments thereby broadening his portfolio and expanding his horizon of returns. International investments also serve as a means of adding different financial instruments to the list when domestic markets are confined and limited by their variety. However, there are 4 types of investments: (1) Government funds/aids: These are funds that flow from one economy to the other with the purpose of aid or assistance to the economy as a whole. These transactions are carried out between the governments.

(2) Cross border loans: A loan arrangement where a government or institution seeks loan financing from a foreign bank is known as cross border loans. Cross border financing became a popular financing vehicle because of its easier accessibility and fewer collateral restriction.

(3) Foreign portfolio investment: When investors express investment interests in foreign companies, they are known as FPIs. These investors may not have long-term interests necessarily but can be traded easily through exchanges.

(4) Foreign direct investment: FDIs are investments made by foreign multinational companies in an economy. Foreign direct investment is more of a long-term concern and takes any form of investing from equities and debts 
to property and assets.

\subsubsection{Theoretical assumption of FDI}

Hymer, Kindleberger and Caves (1997) have propounded the market imperfections approach. The idea starts with the essential assumption that without market imperfections foreign direct investment would never occur. Market imperfection are often caused by goods and factor markets, scale economies, and government imposed regulations, especially tariff and trade barriers that prevent the efficient allocation of resources and distribution of products. In an exceedingly perfect market, the sole vehicle needed to serve a far off market is international trade.

Current literature revolves round the question whether or not traditional theories can explain FDI flows from emerging markets into developed countries, or whether or not they must be extended or replaced by new frameworks. Advocates of conventional theories on the one hand explain the power of Chinese firms to compete through country specific advantages (e.g. Rugman \& Li, 2007; Nguyen, Okrend \& Tang, 2010) or state that the most difference between FDI from developed and emerging economies lies within the weighting of motives (Nicolas \& Thomsen, 2008). Proponents of recent theoretical concepts on the opposite hand argue that Chinese firms are within the process of making a replacement style of business, which internationalizes so as to beat competitive disadvantages both reception and abroad (e.g. Child \& Rodrigues, 2005; Nicolas \& Thomsen, 2008; Luo \& Tung, 2007; Parmentola, 2011; Ramasamy, et al., 2010). In their case study on Chinese FDI in Denmark, Torp, Hansen and Schaumburg-M,ller (2011) find evidence for the applicability of both old and new concepts, while Nolan (2001) states that in accordance with new 28 theories of FDI, large Chinese companies were in an exceedingly weak competitive position at the time of the go global policy in terms of $R \& D$, marketing capabilities and brand development.

2.1.3 Nature of international investment

Before to become one of the biggest economies in the world, China was closed to the international concurrence. The exceptional evolution started with the open door policy that was launched in 1978. The purpose of this policy was to increase the growth of the Chinese economy and to push the integration of the country into the global market. Since then, the country has experienced decades of institutional and domestic economic reforms which has led to an increase in inward and outward FDI (Brown, 2008). Two main dispositions were taken. The first was to develop the export-oriented industry. Therefore, China imported intermediate goods from Asian countries and exported finish goods to Western countries while benefiting from a low labor cost, making China one of the main exporter (Lemoine, 2007). The second was to attract FDI in order to capture global capital (Lemoine, 2013). In 1979, four Special Economic Zones (SEZ) were created to let foreign firms invest with low tax rates and simplified administrative implantation (Naughton, 2007). China that still wanted to have a control on the investment authorized it through Chinese-foreign joint ventures (Brown, 2008). The FDI increased beginning 1990s with opening of new SEZs and Deng XiaoPing speech during his Southern tour to visit the SEZ (Naughton, 2007). In 2000, with the entry to the World Trade Organization (WTO) and the launch of the go global policy, China removed a part of the restrictions on FDI and opened up his doors even more. The 10 liberalization of the economy and the reforms were declared in the 10th Five Year Plan (FYP) (Lemoine, 2007).

However, we can consider the process of the investments in 3 main periods:

Before 2000:

In the $80 \mathrm{~s}$, the government allowed the companies to invest overseas. However, Chinese ODI was almost nonexistent (Hanemann\& Rosen, 2012). This was due to the government focus on the promotion of the FDI, the permission to invest abroad only given to State Owned Enterprise (Cheung, 2009) and the willingness or capacity of only few firms to invest abroad (Hanemann\& Rosen, 2012). Investment was mainly for political motives (Kaartemo, 2007). The increase in ODI accelerated in the second half of the 1980s, when FDI have started to come into the country and when China has been more implicated into the Asian manufacturing network. In 92, Deng XiaoPing continued the liberalization and reform process but there were still highly restrictive controls on it. The aim was to raise the competitiveness of the National Champions to resist to the international concurrence (Hanemann\& Rosen, 2012). These firms mainly invested in developing markets for political investment but also for trade facilitation, as well as the access to raw material dominated by coal, oil and metals (Lake, 2014). There was also a diversification and increase in the manufacturing investment (Kaartemo, 2007).

In the $80 \mathrm{~s}$, the govt allowed the businesses to invest overseas. However, Chinese ODI was almost nonexistent (Hanemann\& Rosen, 2012). This was thanks to the govt specialize in the promotion of the FDI, the permission to speculate abroad only given to State Owned Enterprise (Cheung, 2009) and therefore the willingness or capacity of only few firms to speculate abroad (Hanemann\& Rosen, 2012). Investment was mainly for political motives (Kaartemo, 2007). The rise in ODI accelerated within the last half of the 1980s, when FDI have began to inherit the country and when China has been more implicated into the Asian manufacturing network. In 92, Teng Hsiaoping continued the liberalization and reform process but there were still highly restrictive controls thereon. The aim was to lift the competitiveness of the National Champions to resist to the international concurrence (Hanemann\& Rosen, 2012). These firms mainly invested in developing markets for political investment but also for trade facilitation, also because the access to stuff dominated by coal, oil and metals (Lake, 2014). There was 
also an diversification and increase within the manufacturing investment (Kaartemo, 2007). After 2000:

A second wave happened with the launch of the move out policy in 2000 and also the access to the WTO in 2001. The significantly rise of investment began within the mid 2000 century with the implementation of gradually more liberal rules for ODI that facilitate to speculate abroad, the willingness to catch up the developed countries and also the push of the national champion to travel out with subsidies (Richet, 2017, Jia, 2015, Hanemann\& Rosen, 2012). Within the 2000s, the rise of investment in natural resources with mainly national oil companies and also the increase of 12 Chinese goods demand also pushed the ODI growth (Hanemann\& Rosen, 2012). in step with the survey by IBM Institute for Business Value (2005) and other surveys, whether or not a main motivation of the government has still been to amass natural resources, the primary motive has become the access to new markets. The acquisition of advanced technology has also become to extend (ValtteriKaartemo, 2007). Therefore, whether or not China has been still targeting mainly developing countries (Burghart\& Rossi, 2009), it's slowly began to have an interest in developed economies (Hanneman\&Huotari, 2015).

After the crisis:

After the financial crisis, the slowdown of the global demand for industrial products has generated a slowdown of Chinese export and growth. Imbalances that have risen in the 2000s became urgent to rebalance. Indeed, Chinese has been relying too much on the external demand, investment and exports, and not enough on the household consumption (Lemoine, 2007). Chinese companies have had a weak R\&D capacity, brand image and distribution network (Gipouloux, 2006). Also, the investment balance was imbalanced with the FDI that were accounted for about the double of ODI (UNCTAD, 2017). In order to rebalance the economy through the growth of the domestic consumption, the government notably launched the 12th Five Year Plan (2011-2015), the continuation of the 11th FYP that have already alerted about the imbalances but that was not fulfilled. In the 12th FYP, the government had the willingness to rebalance the economy, move up the value chain with more value added products, focus on the service sector and invest abroad for having a quick access to advanced technology (Ash, et al., 2012), as China needs innovation for a sustainable growth (Naughton, 2007). China has also needed to have access for new markets and gain advantages at home and abroad, human talent and distribution network to strengthen competitiveness in fast growing domestic market (Hanemann\& Rosen, 2012). The government implemented new policies to continue to push firms internationalization with less regulated 13 administrative and new incentives (Hanneman\&Huotar, 2015). He also pushed ODI in sectors of strategic advantage such as telecommunication, renewable energy and environment (Jia, 2015).

\subsection{Empirical literature review}

On one hand, we have the traditional FDI theory that has been used to explain investment from developed countries to develop and developing countries, and their capacity for developing countries are questioned by several authors such as Child \& Rodrigues, (2005) and Rugman\& Li, (2007).The issue in addressing traditional FDI theory is that several of them overlap and use elements from other theories, bringing confusion on the road that separates one from the other.

According to Vasyechko (2012), theory of FDI can be classified into two parallel: the "theory of the firm" and the "international trade theory". Being much associated to each other, international trade theory refers to the general equilibrium model of world trade with models such as "Heckscher-Ohlin-Samuelson", while the former is referring to the micro-level and the motivations from an individual level to expand their operations. The neoclassical theory, with the assumption of perfect competitive markets, developed the first models that shaped our understanding of how FDI worked. General equilibrium models were used to explain how industrialized countries with high labor costs moved their operations to developing countries that were more labor-intensive based. This approach was criticized for not showing the reality accurately, and economic theories moved forward to find alternative explanations.

It was Coase within the late 30s that developed the speculation of transaction costs and inspired Hymer (1960) to develop a theory of FDI, where MNEs went abroad to transfer their know-how and modes of production. Although he provides some basic insights to FDI theory, it's not useful in understanding the motives of a transition economy investing in a very developed economy that already possesses this information. Buckley, Clegg, Cross, Liu, Voss and Zheng (2007) state that internalization takes place when there are imperfections within the home country's capital markets and also the benefits of operating outside outweighs the prices. to grasp where these firms locate, we must check with Dunning's eclectic paradigm or OLI framework.

\section{3- Research objectives, research content/organization of study, and problem statement 3.1 Research objectives}

Among the objectives of this thesis are mainly these two objectives:

(1) Find out the influencing factors of international investment differences between China and Europe.

(2) Policy suggestions for China and the EU to better carry out international investment activities. 


\subsection{Research content/organization of study}

The work will be divided in 5chapters:

Chapter one will be focused on the introduction and Background of the study and some limitations of this study that concern the International Investments between European union and China.

Chapter two is the literature review.

Chapter three will treat the asymmetry of investments between the two economies, China and EU. The lack of this investment will be discussed in the chapter. A comparison of investment that has been done from china and from European countries will be studied.

Chapter four will treat the causes of this lack and the main reasons and factors that influenced the result of this asymmetry of investment. We will talk about the Chinese restrictions that obstruct the reciprocity of the investment, and were the result of this mismatch of those investments.

Chapter five will give some conclusions of the study and propose some suggestions and will suggest a projection for the future.

\subsubsection{Problem statement:}

The principal and general issue of the study is the Asymmetry of the investments between china and European countries. The problems can be sum up as follows:

(1) What are the differences of international Investments between china and Europe?

(2) What are the factors that influence the differences in International Investments between China and Europe?

\subsubsection{Significance of the study}

This study will contribute to the improvement of relations between China and European Union in this way more projects will be taken in consideration and investments will be engaged. I hope that this research will encourage the lectors and also the teachersto be drawn to this new way to see different aspects of this study approach and to adapt it as an effective strategy that will benefit the researchers.

The outcomes to be considered consist of the following: the improvement of relations between the two giant economies in the world, development of a positive attitude towards investors as well; increases technical and academic competencies; creative thinking; and the level of interaction and cooperation.

The findings of this study will redound to the benefit of society considering that international investments play an important role in science of Economics today. Universities that apply recommended approach derived from the results of this study would be able to analyze better the issue of investment asymmetry. The investors will be guided on what should be emphasized to improve their research performance.

The study will help them uncover critical areas in the analysis process that many researchers were not able to explore. Thus, a new theory on international investing.

\section{References}

[1] Branstetter L. Is Foreign direct investment a channel of knowledge spillovers? evidence from Japan's FDI in the United States [J]. Journal of International Economics, 2006, 68(2): 325-344.

[2] Buckley P J, Casson M. The economic theory of the multinational corporate [M]. Macmillan Press LTD, 1976.

[3] Buckley P J, Clegg L J, Cross A R, et al. The determinants of Chinese outward foreign direct investment[J]. Journal of International Business Studies, 2007, 38(4): 499-518.

[4] Buckley P J, Cross A R, Tan H, et al. Historic and emergent trends in Chinese outward direct investment[J]. Management International Review, 2008, 48(6): 715-748.

[5] Cantwell J, Tolentino P E E. Technological accumulation and third world multinationals[J]. International investment and business studies, 1990: 1-58.

[6] Caves D. W., Christensen L. R. and Diewart, W. E. The economic theory of index numbers and measurement of input output and productivity[J]. Econometrica, 1982, (50): 1393-1414.

[7] Caves R E. International corporations: the industrial economics of foreign investment[J]. Economica, 1971, 38(149): 1-27.

[8] Dunning J H, Narula R. The investment development path revisited some emerging issues[J]. London \& New York: Routledge, 1996.

[9] Dunning J H. Explaining the international direct investment position of countries: towards a dynamic or developmental approach[J]. Review of World Economics, 1981, 117(1): 30-64.

[10] Dunning J H. The eclectic paradigm as an envelope for economic and business theories of MNE activity[J]. International Business Review, 2000, 9(2): 163-190.

[11] Dunning J H. The Investment Development Cycle and Third World Multinationals[J]. Routledge, 1986.

[12] Dunning J H. Toward an eclectic theory of international production: some empirical tests[J]. Journal of International Business Studies, 1980, 11(1): 9-31.

[13] Hymer, S. The International operations of national firms: a study of foreign direct investment[M]. The MIT Press, 1960. 
[14] Kojima K. Direct foreign investment: a Japanese model of multi-national business operations[M]. London: Groon Helm, 1978.

[15] Lall S, Chen E, Katz J, et al. The new multinationals: the spread of third world enterprises[J]. Journal of Development Economics, 1985, 19(1): 210-213.

[16] Lall S. Industrial Policy: The role of government in promoting industrial and technological development[J]. UNCTAD review, 1994: 65-90.

[17] Lall S. The new multinationals: the spread of third world enterprises[M]. John Wiley \& Sons, 1983. 